\title{
PROTEIN AND ALKALOID PATTERNS OF THE FLORAL NECTAR IN SOME SOLANACEOUS SPECIES
}

\author{
András Kerchner, ${ }^{1}$ Judit DaróK, ${ }^{1}$ Ivett Bacskay, ${ }^{2}$ Attila Felinger, ${ }^{2}$ \\ GÁBOR JAKAB ${ }^{1}$ and ÁGNES FARKAS ${ }^{3 *}$ \\ ${ }^{1}$ Department of Plant Biology, Faculty of Science, University of Pécs, H-7624 Pécs, Hungary \\ ${ }^{2}$ Department of Analytical and Environmental Chemistry, Faculty of Science, University of Pécs, \\ H-7624 Pécs, Hungary \\ ${ }^{3}$ Institute of Pharmacognosy, Medical School, University of Pécs, H-7624 Pécs, Hungary
}

(Received: November 26, 2014; accepted: March 4, 2015)

\begin{abstract}
The family Solanaceae includes several melliferous plants, which tend to produce copious amounts of nectar. Floral nectar is a chemically complex aqueous solution, dominated by sugars, but minor components such as amino acids, proteins, flavonoids and alkaloids are present as well. This study aimed at analysing the protein and alkaloid profile of the nectar in seven solanaceous species. Proteins were examined with SDS-PAGE and alkaloids were analyzed with HPLC. The investigation of protein profile revealed significant differences in nectar-protein patterns not only between different plant genera, but also between the three Nicotiana species investigated. SDS-PAGE suggested the presence of several Nectarin proteins with antimicrobial activity in Nicotiana species. The nectar of all tobacco species contained the alkaloid nicotine, $N$. tabacum having the highest nicotine content. The nectar of Brugmansia suaveolens, Datura stramonium, Hyoscyamus niger and Lycium barbarum contained scopolamine, the highest content of which was measured in B. suaveolens. The alkaloid concentrations in the nectars of most solanaceous species investigated can cause deterrence in honeybees, and the nectar of $N$. rustica and N. tabacum can be considered toxic for honeybees.
\end{abstract}

Keywords: Brugmansia - Datura - Hyoscyamus - Lycium - Nicotiana - nectar

\section{INTRODUCTION}

Solanaceae are a family comprising approximately 2800 woody and herbaceous plant species in tropical and temperate regions with major species diversity in Central and South America [16]. There is a significant number of melliferous plants in the family, some of which, e.g. Nicotiana tabacum L. [14, 50] and Lycium barbarum L. [37], are apiculturally significant, too. In most representatives of the Solanaceae family, the base of the ovary is surrounded by a ring-shaped nectary, which is characteristic also in the genera investigated in the present study, including Datura, Hyoscyamus, Lycium and Nicotiana [11, 26, 27, 29].

*Corresponding author; e-mail address: agnes.farkas@aok.pte.hu

Abbreviations: HPLC - high performance liquid chromatography; SDS-PAGE - sodium dodecyl sulphate polyacrylamid gel electrophoresis 
Along with the dominant sugars sucrose, glucose and fructose, other carbohydrates can also be found in lower amounts in various floral nectars, e.g. arabinose, galactose, mannose, gentiobiose, lactose, maltose, melibiose, trehalose, melezitose, raffinose and stachyose [5]. Besides sugars, nectar may contain glycosides, phenolic compounds, amino acids, reducing acids, fragrance compounds, lipids, proteins, alkaloids, antibiotics and vitamins [6, 38, 49]. Some of these minor nectar-components, such as phenolic compounds [10-11, 30, 32], amino acids [10-12, 24, 30-32, 43], antioxidant and reducing organic acids $[12,20,31]$, sesquiterpenes, aromatic alcohols and aldehydes [44], as well as lipids [10,30,31] were reported in the floral nectar of certain Solanaceae species.

The protein content of nectar has already been analyzed in some solanaceous taxa $[12-13,19-23,31,34,40-41,51,53,60,63]$. The amino acid sequence and functions of the so-called Nectarin proteins were determined in the floral nectar of the ornamental tobacco hybrid LxS8 (Nicotiana langsdorffi $\times$ Nicotiana sanderae var. LxS8) $[19-21,53]$. These proteins were shown to be enzymes with antimicrobial activity playing a key role in protecting the gynoecium against microorganisms. Other enzymes including ribonucleases, desoxyribonucleases, a peroxidase, an endochitinase, the presumed fructokinase which can prevent microbial colonization in the nectar of Petunia hybrida; as well as ribonucleases, a peroxidase and a chitinase were identified in the nectar of Nicotiana langsdorffi $\times$ Nicotiana sanderae var. LxS8 [40-41].

Pyridine-, sterane- and tropane-alkaloids are characteristic for the Solanaceae family $[1-2,15,42]$. As early as the 1960 s it was presumed that these alkaloids, as secondary metabolites, may be secreted into the nectar as well $[25,35,39,62]$. The accumulation of allelochemicals (including alkaloids) occurring in nectar is presumed to be a result of selective secretion $[48,61]$. Scopolamine and atropine could be isolated also from honeys originating from flowers of plants with high levels of these alkaloids [7]. In most cases the alkaloid-content of pollen and nectar is significantly lower than that of the leaves, flowers and other floral parts [17, 28], which does not allow the detection of these compounds in nectar samples with low-sensitivity analytical methods, as e.g. thin layer chromatography (TLC). This can be in the background of earlier failed attempts to detect alkaloids in nectar samples of solanaceous plants [4, 12, 31-32]. However, by using modern analytical techniques such as gas chromatography (GC) and high performance liquid chromatography (HPLC), a number of researchers have already succeeded in identifying as well as quantitatively determining the characteristic alkaloids in the floral nectar of various Solanaceae species [3, 13, 17, 28-29, 44, 57]. Some of these alkaloids, like hyoscyamine, scopolamine, tropin, nicotine and anabasine were reported to cause feeding deterrence to animal pollinators $[28,55,57]$. Alkaloids, along with some non-protein amino acids and phenolic components, belong to the most common nectar toxins [52].

The present study examines the protein profile of the floral nectar of Nicotiana tabacum L., N. rustica L., N. alata Link et Otto, Cestrum $\times$ 'Newellii' (Veitch) Nicholson, Lycium barbarum L. and Brugmansia suaveolens Persoon; the nicotine content of the floral nectar in the above three Nicotiana species, as well as the atro- 
pine- and scopolamine-content of the floral nectar samples of L. barbarum, B. suaveolens, Datura stramonium L. and Hyoscyamus niger L. In addition to providing new data about minor nectar components of species not investigated previously, the possible roles of the examined nectar-components are discussed.

\section{MATERIALS AND METHODS}

\section{Investigated plant taxa}

Investigated plant taxa included Brugmansia suaveolens Persoon, Cestrum $\times$ 'Newellii' (Veitch) Nicholson, Datura stramonium L., Hyoscyamus niger L., Lycium barbarum L., Nicotiana tabacum L., N. rustica L. and N. alata Link et Otto. Voucher specimens of each investigated species were deposited at the herbarium of the Department of Plant Biology, University of Pécs, Hungary.

\section{Nectar sampling}

Floral nectar was extracted with glass capillary tubes bearing microlitre marks (CM Scientific Ltd., Silsden, United Kingdom) from flowers of 10-60 specimens (depending on the species) in the Botanical Garden of the University of Pécs, Hungary. Nectars were sampled on several different occasions between May 2005 and October 2006, during the flowering period of each species. The pooled nectar samples were stored in Eppendorf tubes at $-20^{\circ} \mathrm{C}$ until further use.

\section{Determination of total protein concentration}

Protein quantity determination was performed according to the procedure described in [18], using bovine serum albumin (BSA) as calibration standard.

\section{SDS-PAGE separation of nectar proteins}

The separation of nectar proteins was performed by sodium dodecyl sulphate polyacrylamide gel electrophoresis (SDS-PAGE) according to [47]. Fifteen $\mu 1$ of raw nectar per species was loaded in one pocket, using a $15 \%(\mathrm{w} / \mathrm{v})$ separating gel in mini-gel system (Bio-Rad $\left.{ }^{\mathrm{TM}}\right)$. Protein molecular weight markers (Fermentas ${ }^{\mathrm{TM}}$ ) were used as standards. The proteins were made visible by using PageBlue ${ }^{\mathrm{TM}}$ Protein Staining Solution (Fermentas ${ }^{\mathrm{TM}}$ ). Individual protein bands were evaluated compared to molecular weight markers. 


\section{HPLC analysis of alkaloids in the nectar}

HPLC analysis was performed in the months of February-April of 2007. Nectar samples were diluted twofold with $10 \mathrm{mM}$ sodium phosphate buffer, then filtered with a syringe filter (Millex-HN, $0.45 \mu \mathrm{m}$, nylon, $33 \mathrm{~mm}$, non-sterile; Merck Millipore, Darmstadt, Germany).

The high pressure liquid chromatographic (HPLC) analysis of various alkaloids was performed using a Shimadzu liquid chromatograph [two pumps (LC-10ADVP), degasser (DGU-14A), manual injector with a $20 \mu \mathrm{L}$ loop, diode array detector (SPD10AVP) and a computer data acquisition station]. The column used was a Phenomenex Synergy $10 \mu$ Hydro-RP $80(250 \mathrm{~mm} \times 4.6 \mathrm{~mm}$, average particle size $10 \mu \mathrm{m})$. All measurements were done at ambient temperature. Each properly prepared nectar sample was run three times in the HPLC-device.

The analysis of scopolamine and atropine was performed according to the procedure of $[33,46]$, with modifications. Scharlau HPLC grade methanol and $10 \mathrm{mM}$ sodium phosphate buffer, $\mathrm{pH} 3.0$ were used. The flow rate used was $1.00 \mathrm{~mL} / \mathrm{min}$. The eluent contained 35\% methanol. The components were detected at $228 \mathrm{~nm}$. The limit of detection (LOD) was $1.08 \cdot 10^{-3} \mathrm{mg} / \mathrm{mL}$ and $1.28 \cdot 10^{-3} \mathrm{mg} / \mathrm{mL}$ for scopolamine and atropine, respectively. The concentration limit of quantification (LOQ) was $3.28 \cdot 10^{-3} \mathrm{mg} / \mathrm{mL}$ and $3.87 \cdot 10^{-3} \mathrm{mg} / \mathrm{mL}$ for scopolamine and atropine, respectively.

Nicotine was determined according to the method of Tambwekar et al. [58], with minor changes. Scharlau HPLC grade methanol and $10 \mathrm{mM}$ sodium phosphate buffer, $\mathrm{pH} 6.8$ were used. The flow rates used were $1.00 \mathrm{~mL} / \mathrm{min}$. The eluent contained $65 \%$

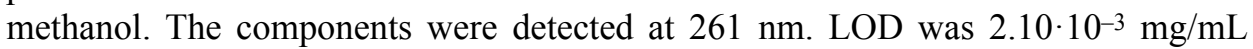
while LOQ was determined as $6.23 \cdot 10^{-3} \mathrm{mg} / \mathrm{mL}$.

LCMS solution (Shimadzu) software was used to control the chromatographic system and for data processing.

\section{RESULTS}

\section{Protein content of the floral nectar}

The analysis of nectar proteins revealed that each of the investigated plant taxa contained proteins in their floral nectar, although in highly variable amounts (Table 1). Concentrations varied not only between different genera, but also within the Nicotiana genus. In accordance with the concentration values, the strongest protein bands in the SDS-PAGE gel can be seen in N. rustica (Fig. 1), which contained an order of magnitude higher concentration of nectar proteins compared to N. tabacum. Further analysis of the protein pattern with SDS-PAGE included the taxa with protein concentrations exceeding $50 \mu \mathrm{g} / \mathrm{mL}$.

Analysis by SDS-PAGE revealed the presence of one major protein band of 60 $\mathrm{kDa}$ in both $N$. alata and N. rustica (Fig. 1). Three less prominent bands can be seen 
Table 1

Nectar protein concentrations $(\mu \mathrm{g} / \mathrm{mL})$ of various solanaceous species, measured according to Bradford [18], using bovine serum albumin (BSA) as calibration standard

\begin{tabular}{|l|c|c|c|c|c|c|}
\hline Genus name & Brugmansia & Cestrum $\times$ & Lycium & \multicolumn{3}{|c|}{ Nicotiana } \\
\hline Species name & suaveolens & newellii & barbarum & alata & rustica & tabacum \\
\hline Concentration $(\mu \mathrm{g} / \mathrm{mL})$ & 88 & 44 & 131 & 84.5 & 265.5 & 21 \\
\hline
\end{tabular}

Data are from a single series of measurements.

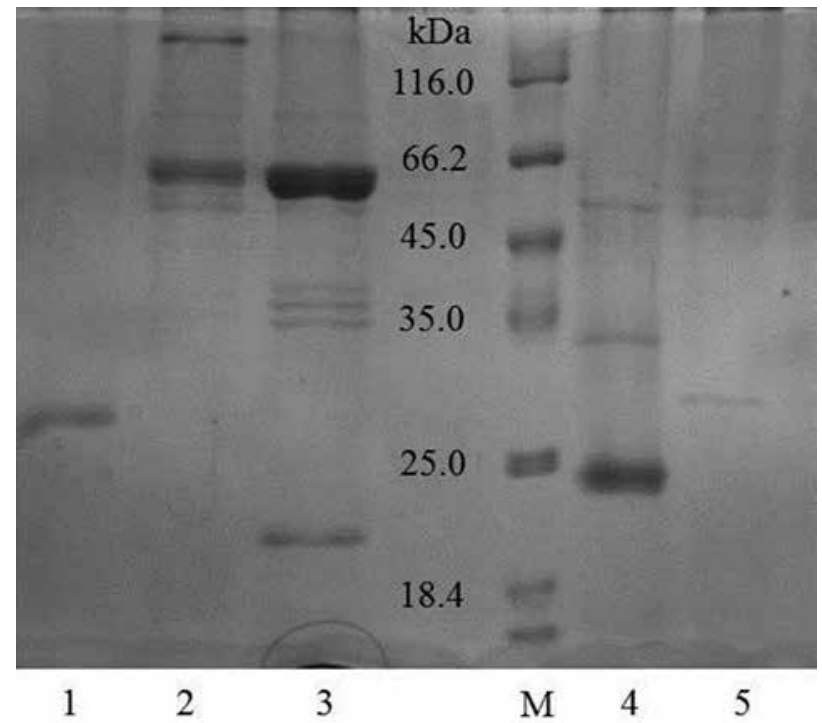

Fig. 1. SDS-PAGE separation of nectar proteins. Lane 1: B. suaveolens, Lane 2: N. alata, Lane 3: N. rustica, M: Protein Molecular Weight Markers (from above to below): $116.0 \mathrm{kDa}, 66.2 \mathrm{kDa}, 45.0 \mathrm{kDa}$, $35.0 \mathrm{kDa}, 25.0 \mathrm{kDa}, 18.4 \mathrm{kDa}$, Lane 4: L. barbarum, Lane 5: C. × 'Newellii'. The nectar samples were run at least three times and, in each case, we received similar protein profiles. In each analysis, $15 \mu \mathrm{L}$ raw nectar was loaded in gel

between 35.0 and $45.0 \mathrm{kDa}$, and a stronger one halfway between 18.4 and $25.0 \mathrm{kDa}$ in N. rustica. The predominant protein in B. suaveolens occurs between 25 and 35 $\mathrm{kDa}$, whereas in L. barbarum slightly below $25 \mathrm{kDa}$ (Fig. 1).

\section{Alkaloid content of the floral nectar}

The HPLC analysis of floral nectar samples revealed that each investigated taxon contained the alkaloid specific to the given plant genus, confirming that the alkaloids 
Table 2

Alkaloid concentration of floral nectar samples

\begin{tabular}{|l|c|c|}
\hline \multicolumn{1}{|c|}{ Plant } & Alkaloid & Concentration $(\mu \mathrm{g} / \mathrm{mL} \pm \mathrm{SE})$ \\
\hline Nicotiana alata & \multirow{4}{*}{ nicotine } & $0.79 \pm 0.09$ \\
\hline Nicotiana rustica & & $2.53 \pm 0.14$ \\
\hline Nicotiana tabacum & & $5.89 \pm 0.40$ \\
\cline { 1 - 1 } Hyoscyamus niger & \multirow{4}{*}{ scopolamine } & $2.92 \pm 0.13$ \\
\hline Lycium barbarum & & $24.28 \pm 4.89$ \\
Datura stramonium & & $99.01 \pm 3.20$ \\
\hline Brugmansia suaveolens & & $149.80 \pm 6.01$ \\
& &
\end{tabular}

Data are means \pm standard error (SE) calculated from three measurements. The quantity of atropine remained below the concentration limit of quantification $(\mathrm{LOQ}=3.87 \mu \mathrm{g} / \mathrm{mL})$.

characteristic to various organs of a plant are secreted into the nectar, as well. Accordingly, nicotine was detected in the nectar samples of all three Nicotiana species, while scopolamine was identified in the samples from four other solanaceous genera (Table 2). Characteristic chromatograms of nicotine and scopolamine are demonstrated by Figs 2 and 3, respectively.

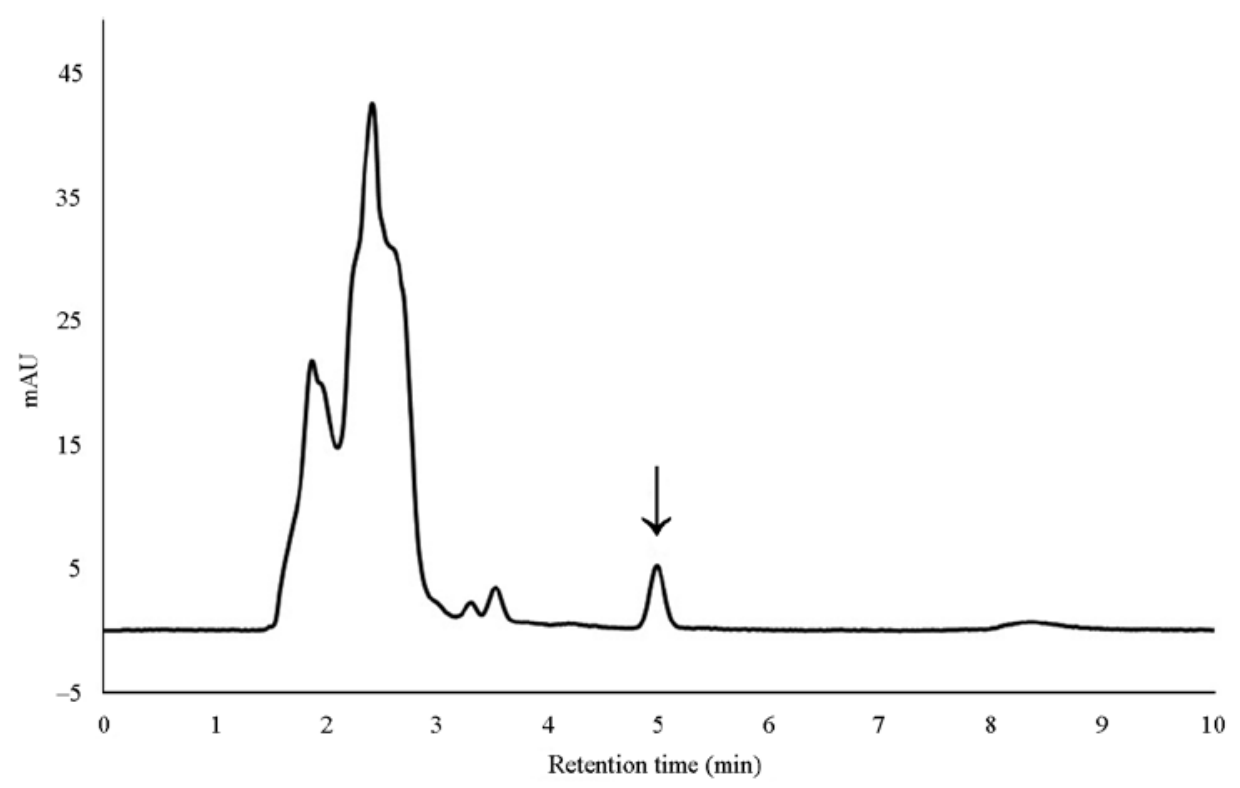

Fig. 2. Chromatogram of nicotine in Nicotiana tabacum nectar sample, $t_{R}=4.99 \mathrm{~min}$ (arrow) 


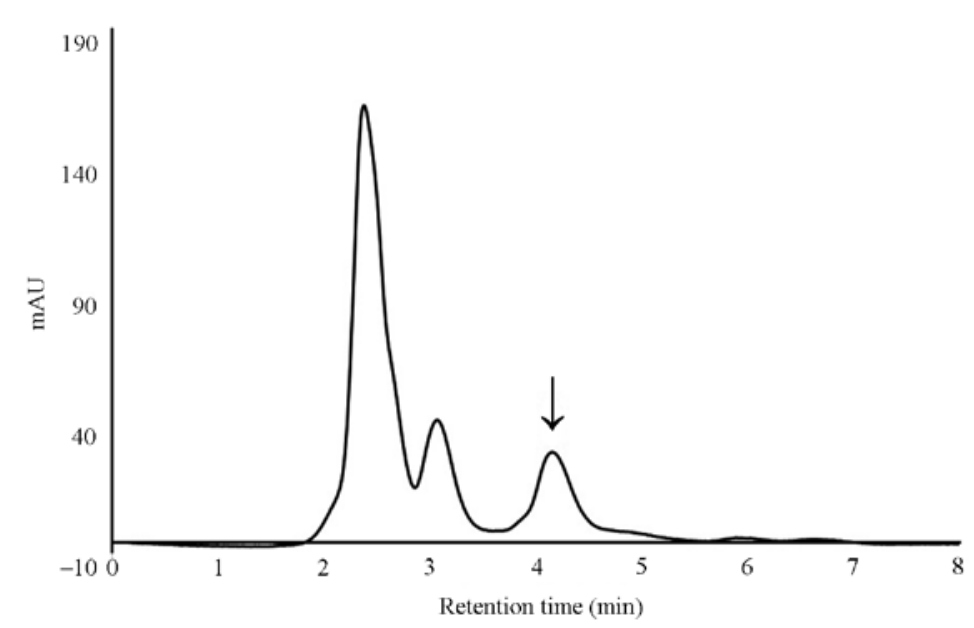

Fig. 3. Chromatogram of scopolamine in Brugmansia suaveolens nectar sample, $t_{R}=4.15 \mathrm{~min}$ (arrow)

\section{DISCUSSION}

Floral nectar protein concentrations 47.0, 42.2, 20.5 and $25.7 \mu \mathrm{g} / \mathrm{mL}$ had been measured for $N$. attenuata, N. tabacum, Datura aurea and Cestrum purpureum, respectively, in the same order of magnitude [13,63] as in our study. Evaluating various Nicotiana taxa, N. rustica had higher nectar protein concentrations, compared to either the other two species involved in our study (Table 1), or to Nicotiana species investigated previously [13, 23, 63].

The 5 major proteins in the floral nectar of the ornamental tobacco $N$. langsdorffii $\times N$. sanderae var. LxS8, labelled Nectarin 1 to 5 were found to accumulate up to the concentrations of $240-250 \mu \mathrm{g} / \mathrm{mL}$, which equals approximately the total protein concentration $[19,23,60]$. This concentration is much closer to the values measured by us in $N$. rustica $(265.5 \mu \mathrm{g} / \mathrm{mL})$ than to the nectar protein concentration of $N$. alata $(84.5 \mu \mathrm{g} / \mathrm{mL})$, even though a considerable part of the gene pool of $N$. alata can be found in the LxS8 outcrossing ornamental tobacco, since $N$. $\times$ sanderae is a hybrid of $N$. alata and N. forgetiana.

From the investigated solanaecous taxa, Nicotiana species share the highest number of identities in their pattern of protein bands, which can be attributed to their taxonomic proximity, and the Nicotiana genus significantly differs from the other 3 solanaceous species investigated.

Brugmansia $\times$ candida had been described as a Nectarin I (NEC1)-positive plant species [19]. In the case of loading crude nectar (without heat treatment) into the gel, NEC1 was found to migrate in a monomer form with a molecular weight of $29 \mathrm{kDa}$ and as an oligomer molecule with a weight of $165 \mathrm{kDa}$. In the current study, however, only the $29 \mathrm{kDa}$ band corresponding to this protein could be detected in B. suaveolens (Fig. 1). 
Our results are congruent with those of [19] who claimed that N. alata is a NEC1positive plant species. The uppermost band $(165 \mathrm{kDa})$ in Lane 2 in Fig. 1 can be identified as the oligomer form of NEC1 with superoxide dismutase activity. Other nectar protein bands of Nicotiana species investigated in the present study also correspond to Nectarin proteins. The more powerful band slightly below the $66.2 \mathrm{kDa}$ marker in both $N$. alata and $N$. rustica is the Nectarin IV (NEC4) protein with $60 \mathrm{kDa}$ molecular weight and poligalacturonase inhibitor function [53] and it is a tandem of the Nectarin V (NEC5) protein with glucose oxidase activity and a molecular weight of 61-65 kDa, described by Carter [21]. The protein band faintly visible in N. rustica between 45 and $35 \mathrm{kDa}$ can be considered to be the Nectarin III (NEC3) protein with bifunctional monodehydroascorbate reductase and carbonic anhydrase activities and a molecular weight of $40 \mathrm{kDa}$, as described by Carter and Thornburg [20]. The protein at the same height with the $35 \mathrm{kDa}$ molecular weight marker can be identified as the Nectarin II (NEC2) protein with a molecular weight of $35 \mathrm{kDa}$ which is to be qualified as the degradation product of NEC3.

The protein profile of $N$. rustica is the most similar to that of $N$. alata, however, the bands of the NEC2, NEC3 and the NEC4/NEC5 doublet are sharper and more clearly visible in $N$. rustica. The presumed NEC1 is positioned elsewhere in N. rustica compared with $N$. alata. The molecular weight of the protomer subunit of Nectarin I is $22.5 \mathrm{kDa}$ [19], and in the case of $N$. rustica a protein band is visible with a molecular weight similar to this between 25 and $18.4 \mathrm{kDa}$.

As far as the quantity of nectar-alkaloids is concerned, to date there are only a few exact data related to the Solanaceae family. The total alkaloid concentration in the nectar of Atropa belladonna, B. aurea (yellow flowers), B. aurea (red flowers) and $N$. tabacum was determined as $273,91.7,7.34$ and $0.166 \mu \mathrm{g} / \mathrm{g}$, respectively [28]. The concentration of scopolamine was $57.04 \mu \mathrm{g} / \mathrm{g}$ and $4.57 \mu \mathrm{g} / \mathrm{g}$ in yellow flowered and red flowered $B$. aurea, respectively. In contrast, we measured higher concentrations of scopolamine in the nectar of $B$. suaveolens (Table 2). The concentration range of scopolamine and atropine was determined as $11.00-400.04 \mu \mathrm{g} / \mathrm{mL}$ and $0.19-37.00$ $\mu \mathrm{g} / \mathrm{mL}$ in various Datura species (D. innoxia, D. metel, D. meteloides, D. tatula), respectively, in a previous study [17]. The current study detected scopolamine for the first time in the floral nectar of D. stramonium and its concentration fitted within the range determined in Boros et al. [17]. We reported for the first time the presence of scopolamine in the floral nectar of Hyoscyamus niger and Lycium barbarum. The above data suggest that the concentration of alkaloids in the nectar can vary within wide ranges, not only within the same genus, but also in different varieties of the same species.

Previous studies determined $0.1-0.5 \mu \mathrm{g} / \mathrm{mL}$ and $0.6-5 \mu \mathrm{g} / \mathrm{mL}$ as the concentration range of nicotine and anabasine, respectively, in the nectar of $N$. glauca [57]; whereas in $N$. tabacum $0.33 \mu \mathrm{g} / \mathrm{mL}$ was measured as the concentration of nicotine and anabasine [3]. In the nectar of $N$. attenuata the concentration of nicotine was $3 \pm 0.35$ $\mu \mathrm{g} / \mathrm{mL}$ [13]. The mean concentrations of nicotine measured by us in the nectar of $N$. alata and $N$. rustica were within the range of $0.79-2.5 \mu \mathrm{g} / \mathrm{mL}$ which was found to be attractive and even addictive for honeybees [55], whereas nicotine concentrations 
in $N$. tabacum nectar slightly exceeded $5 \mu \mathrm{g} / \mathrm{mL}$, which can already have aversive effect. In a different study, adult honeybee workers and even their larvae were reported to tolerate naturally occurring nectar nicotine-concentrations $(0.1-5 \mu \mathrm{g} / \mathrm{mL})$, with no disadvantageous effect on their emergence success and survival [45]. The same authors claimed that a nicotine concentration below $4.8 \mu \mathrm{g} / \mathrm{mL}$ did not cause deterrence in honeybee foraging behaviour. Due to their detoxificating enzymes, honeybees show physiological plasticity against pesticides and special floral metabolites $[56,59]$. However, a higher nicotine concentration $(50 \mu \mathrm{g} / \mathrm{mL})$ was found to cause the post-emergence mortality of the larvae [55]. In another set of honeybee feeding experiments [28] the $\mathrm{ED}_{50}$ value (the concentration of alkaloid which caused $50 \%$ of the maximal possible effect) for both nicotine and scopolamine was determined as 0.3 $\mu \mathrm{g} / \mathrm{mL}$, i.e. already such low concentrations of the above alkaloids were found to cause deterrence. For pyridine alkaloids a dose-dependent deterrence was reported by [57]. According to the results of Detzel and Wink [28] the alkaloid concentrations measured in all the nectars in our study (Table 2) would have a negative effect on the foraging behaviour of honeybees; and even if the data of Singaravelan et al. [54] are taken into consideration, at least one of the three Nicotiana species investigated would deter honeybees from feeding on its nectar. The $\mathrm{LD}_{50}$ value for nicotine in the nectar was determined as $2 \mu \mathrm{g} / \mathrm{mL}$ [28], which means that, according to our data, the nectar of both $N$. rustica and $N$. tabacum could be toxic for honeybees.

\section{REFERENCES}

1. Adams, M., Wiedenmann, M., Tittel, G., Bauer, R. (2006) HPLC-MS trace analysis of atropine in Lycium barbarum berries. Phytochem. Anal. 17, 279-283.

2. Adibfar, E., Dilmaghani, K., Hekmat Shoar, H. (2011) Alkaloid contents of Hyoscyamus niger L. at different organs in different growth stages. Iranian J. Plant Physiol. 1, 187-192.

3. Adler, L. S., Wink, M., Distl, M., Lentz, A. J. (2006) Leaf herbivory and nutrients increase nectar alkaloids. Ecol. Letters 9, 960-967.

4. Baker, H. G., Baker, I. (1975) Studies of nectar-constitution and pollinator-plant coevolution. In: Gilbert, L. E., Raven, P. H. (eds) Coevolution of Animals and Plants. University of Texas Press, Austin, pp. 100-140.

5. Baker, H. G., Baker, I. (1983) Floral nectar sugar constituents in relation to pollinator type. In: Jones, C. E., Little, R. J. (eds) Handbook of Experimental Pollination Biology. Van Nostrand Reinhold, New York, pp. 117-141.

6. Baker, H. G., Baker, I. (1983) A brief historical review of the chemistry of floral nectar. In: Bentley, B., Elias, T. S. (eds) The Biology of Nectaries. Columbia University Press, New York, pp. 126-152.

7. Barragan de Dominguez, M. C. (1973) Contribucion al estudio de mieles toxicas colombianas. Revista Colombiana de Ciencias Quimíco-Farmacéuticas 2, 5-31.

8. Bernardello, L. M. (1986) The nectary exudate of Lycium cestroides (Solanaceae). Biotropica 18, 241-243.

9. Bernardello, L. M. (1987) Comparative floral morphology in Lycieae (Solanaceae). Brittonia 39, $112-129$.

10. Bernardello, L. M., Galetto, L., Jaramillo, J., Grijalba, E. (1994) Floral nectar chemical composition of some species from Reserva Río Guajalito, Ecuador. Biotropica 26, 113-116.

11. Bernardello, G., Galetto, L., Forcone, A. (1999) Floral nectar chemical composition of some species from Patagonia II. Biochem. Syst. Ecol. 27, 779-790. 
12. Bernardello, G., Galetto, L., Anderson, G. J. (2000) Floral nectary structure and nectar chemical composition of some species from Robinson Crusoe Island (Chile). Can. J. Bot. 78, 862-872.

13. Bezzi, S., Kessler, D., Diezel, C., Muck, A., Anssour, S., Baldwin, I. T. (2010) Silencing NaTPI expression increases nectar germin, Nectarins, and hydrogen peroxide levels and inhibits nectar removal from plants in nature. Plant Physiol. 152, 2232-2242.

14. Bhuiyan, K. H., Hossain, M. M., Bari, M. N., Khanam, M. R. (2002) Identification of bee plants and analysis of honey collected from different plant sources. Pakistan J. Biol. Sci. 5, 1199-1201.

15. Bieri, S., Varesio, E., Veuthey, J.-L., Muńoz, O., Tseng, L.-H., Braumann, U., Spraul, M., Christen, P. (2006) Identification of isomeric tropane alkaloids from Schizanthus grahamii by HPLC-NMR with loop storage and HPLC-UV-MS/SPE-NMR using a cryogenic flow probe. Phytochem. Anal. 17, 78-86.

16. Borhidi, A. (1998) The Evolutionary Taxonomy of Angiosperms. Nemzeti Tankönyvkiadó, Budapest. [in Hungarian]

17. Boros, B., Farkas, Á., Jakabová, S., Bacskay, I., Kilár, F., Felinger, A. (2010) LC-MS quantitative determination of atropine and scopolamine in the floral nectar of Datura species. Chromatographia $71,43-49$.

18. Bradford, M. M. (1976) A rapid and sensitive method for the quantitation of microgram quantities of protein utilizing the principles of protein-dye binding. Anal. Biochem. 72, 248-254.

19. Carter, C., Thornburg, R. W. (2000) Tobacco Nectarin I: Purification and characterization as a germinlike, manganese superoxide dismutase implicated in the defense of floral reproductive tissues. J. Biol. Chem. 275, 36726-36733.

20. Carter, C. J., Thornburg, R. W. (2004) Tobacco Nectarin III is a bifunctional enzyme with monodehydroascorbate reductase and carbonic anhydrase activities. Plant Mol. Biol. 54, 415-425.

21. Carter, C. J., Thornburg, R. W. (2004) Is the nectar redox cycle a floral defense against microbial attack? Trends in Plant Sci. 9, 320-324.

22. Carter, C. J., Thornburg, R. W. (2004) Tobacco Nectarin V is a flavin-containing berberine bridge enzyme-like protein with glucose oxidase activity. Plant Physiol. 134, 460-469.

23. Carter, C., Graham, R. A., Thornburg, R. W. (1999) Nectarin I is a novel, soluble germin-like protein expressed in the nectar of Nicotiana sp. Plant Mol. Biol. 41, 207-216.

24. Carter, C., Shafir, S., Yehonatan, L., Palmer, R. G., Thornburg, R. (2006) A novel role for proline in plant floral nectars. Naturwissenschaften 93, 72-79.

25. Cheeke, P. R., Shull, L. R. (1985) Natural Toxicants in Feeds and Poisonous Plants. Avi Publishing Company, Inc., Westport, Connecticut.

26. Cocucci, A. A., Galetto, L. (1992) Nectary structure and floral syndrome in Nicotiana (Solanaceae). Darwiniana 31, 151-157. [in Spanish]

27. Darók, J. (1984) Floral nectaries of Hungarian Solanaceae species. Doctoral dissertation, Szeged. pp. 70-82. [in Hungarian]

28. Detzel, A., Wink, M. (1993) Attraction, deterrence or intoxication of bees (Apis mellifera) by plant allelochemicals. Chemoecol. 4, 8-18.

29. Farkas, Á., Kerchner, A., Déri, H., Boros, B., Darók, J. (2011) Nectary structure and nectar production of various Datura species. Int. J. Plant Reprod. Biol. 3, 31-35.

30. Forcone, A., Galetto, L., Bernardello, L. (1997) Floral nectar chemical composition of some species from Patagonia. Biochem. Syst. Ecol. 25, 395-402.

31. Galetto, L. (1991) On the nectar and the nectaries of some species of Nicotiana (Solanaceae) Kurtziana 21, 165-176. [in Spanish]

32. Galetto, L., Bernardello, G., Sosa, C. A. (1998) The relationship between floral nectar composition and visitors in Lycium (Solanaceae) from Argentina and Chile: what does it reflect? Flora 193, 303-314.

33. Gören, A. C., Bilsel, G., Bilsel, M., Yenisoy-Karakaş, S., Karakaş, D. (2004) Simple high-performance liquid chromatographic method for determination of atropine and obidoxime in a parenteral injection device. J. Chrom. A 1057, 237-239. 
34. Gracie, C. (1993) Pollination of Cyphomandra endopogon var. endopogon (Solanaceae) by Eufriesea spp. (Euglossini) in French Guiana. Brittonia 45, 39-46.

35. Grant, V., Grant, K. A. (1983) Behavior of hawkmoths on flowers of Datura meteloides. Bot. Gazette 144, 280-284.

36. Gulyás, S., Nagyné-Bíró, M., Komendar, V. I. (1990) Morphological structure and productivity of nectaries of the Nicotiana tabacum L. varieties in the basin of the Tissa river in the Ukrainian SSR (USSR). Ukrayinskyi Botanichnyi Zhurnal 47, 16-19. [in Russian]

37. Halmágyi, L., Keresztesi, B. (1975) Méhlegelö (The bee pasture). Akadémiai Kiadó, Budapest. [in Hungarian]

38. Heil, M. (2011) Nectar: generation, regulation and ecological functions. Trends in Plant Sci. 16, 191-200.

39. Heiser, C. B. (1969) Nightshades: The Paradoxical Plants. W. H. Freeman, San Francisco.

40. Hillwig, M. S., Liu, X., Liu, G., Thornburg, R. W., MacIntosh, G. S. (2010) Petunia nectar proteins have ribonuclease activity. J. Exper. Bot. 61, 2951-2965.

41. Hillwig, M. S., Kanobe, C., Thornburg, R. W., MacIntosh, G. C. (2011) Identification of S-RNase and peroxidase in petunia nectar. J. Plant Physiol. 168, 734-738.

42. Hunziker, A. T. (2001) Genera Solanacearum: The Genera of Solanaceae Illustrated, Arranged According to a New System. A.R.G. Gantner Verlag K. G., Ruggell, Lichtenstein.

43. Kaczorowski, R. L., Gardener, M. C., Holtsford, T. P. (2005) Nectar traits in Nicotiana section Alatae (Solanaceae) in relation to floral traits, pollinators, and mating system. Am. J. Bot. 92, 1270-1283.

44. Kessler, D., Baldwin, I. T. (2006) Making sense of nectar scents: the effects of nectar secondary metabolites on floral visitors of Nicotiana attenuata. Plant J. 49, 840-854.

45. Köhler, A., Pirk, C. W. W., Nicolson, S. W. (2012) Honeybees and nectar nicotine: deterrence and reduced survival versus potential health benefits. J. Insect Physiol. 58, 286-292.

46. Kursinszki, L., Hank, H., László, I., Szőke, É. (2005) Simultaneous analysis of hyoscyamine, scopolamine, $6 \beta$-hydroxyhyoscyamine and apoatropine in Solanaceous hairy roots by reversed-phase high-performance liquid chromatography. J. Chromatogr. A 1091, 32-39.

47. Laemmli, U. K. (1970) Cleavage of structural proteins during the assembly of the head of bacteriophage T4. Nature 227, 680-685.

48. Lüttge, U. (1977) Nectar composition and membrane transport of sugars and amino acids: a review on the present state of nectar research. Apidologie 8, 305-319.

49. Martini, M., Schmid, A., Hess, D. (1990) Antibiotics, sugars, and amino acids in nectar of Rhododendron and Pipthanthus species from Nepal. Botanica Acta 103, 343-348.

50. Oddo, L. P., Piana, L., Bogdanov, S., Bentanol, A., Gotsiou, P., Kerkvliet, J., Martin, P., Morlot, M., Valbuena, O., Ruoff, K., von der Ohe, K. (2004) Botanical species giving unifloral honey in Europe. Apidologie 35, S82-S93.

51. Park, S., Thornburg, R. W. (2009) Biochemistry of nectar proteins. J. Plant Biol. 52, 27-34.

52. Rhoades, D. F., Bergdahl, J. C. (1981) Adaptive significance of toxic nectar. Am. Naturalist 117, 798-803.

53. Saqlan Naqvi, S. M., Harper, A., Carter, C., Ren, G., Guirgis, A., York, W. S., Thornburg, R. W. (2005) Nectarin IV, a potent endoglucanase inhibitor secreted into the nectar of ornamental tobacco plants. Isolation, cloning, and characterization. Plant Physiol. 139, 1389-1400.

54. Singaravelan, N., Nee'man, G., Inbar, M., Izhaki, I. (2005) Feeding responses of free-flying honeybees to secondary compounds mimicking floral nectars. J. Chem. Ecol. 31, 2791-2804.

55. Singaravelan, N., Inbar, M., Nee'man, G., Distl, M., Wink, M., Izhaki, I. (2006) The effects of nectarnicotine on colony fitness of caged honeybees. J. Chem. Ecol. 32, 49-59.

56. Smirle, M. J., Winston, M. L. (1988) Detoxifying enzyme activity in worker honeybees: an adaptation for foraging in contaminated ecosystems. Can. J. Zool. 66, 1938-1942.

57. Tadmor-Melamed, H., Markman, S., Arieli, A., Distl, M., Wink, M., Izhaki, I. (2004) Limited ability of Palestine Sunbirds Nectarinia osea to cope with pyridine alkaloids in nectar of Tree Tobacco Nicotiana glauca. Functional Ecol. 18, 844-850. 
58. Tambwekar, K. R., Kakariya, R. B., Garg, S. (2003) A validated high performance liquid chromatographic method for analysis of nicotine in pure form and from formulations. J. Pharmaceut. Biomed. Anal. 32, 441-450.

59. Terriere, L. C., Yu, S. J. (1974) Induction of detoxifying enzymes in insects. J. Agric. Food Chem. 22, 366-373.

60. Thornburg, R. W., Carter, C., Powell, A., Mittler, R., Rizhsky, L., Horner, H. T. (2003) A major function of the tobacco floral nectary is defense against microbial attack. Plant Syst. Evol. 238, 211-218.

61. Vogel, S. (1978) Evolutionary shifts from reward to deception in pollen flowers. In: Richards, A. (ed.) The Pollination of Flowers by Insects. Academic Press, London, pp. 89-96.

62. Willaman, J. J., Li, H. L. (1970) Alkaloid-bearing plants and their contained alkaloids, 1957-1968. Lloydia 33 (Suppl.), 1-286.

63. Zha, H. G., Flowers, V. L., Yang, M., Chen, L. Y., Sun, H. (2012) Acidic $\alpha$-galactosidase is the most abundant nectarin in floral nectar of common tobacco (Nicotiana tabacum). Annals Bot. 109, 735745. 